\title{
Teacher's belief and its implication on integrating CALL
}

\author{
Desy Nur Fakhomah', Abdul Asib², Dewi Rochsantiningsih3 \\ Universitas Sebelas Maret ${ }^{1,2,3}$ \\ ${ }^{1}$ Correspondence: dnurfakhomah@gmail.com
}

\begin{abstract}
These days, the development of science and technology achieved has contributed to the advance in language teaching and learning. Nowadays, language teachers utilize computer and internet with their software and facilities for the purpose of teaching and learning activities in the classrooms. The use of computer assisted language learning (CALL) for language teaching and learning is not only at formal school such as elementary school, high school and university, but it is also used at informal school such as Sanggar Kegiatan Belajar (SKB). Therefore, this study aims to investigate teacher's belief and its implication on integrating CALL in English class at SKB (Sanggar Kegiatan Belajar). For reaching the aims, a qualitative method is conducted towards the participant who has used CALL for language teaching and learning at SKB. The participant is purposively selected in order to get sufficient data of this research. The questionnaire, interview and classroom observation are used for collecting data. The result of this study shows that the teacher has positive belief towards CALL integration in English teaching and learning process. Besides, the participant also implies the CALL integration by explaining materials through Power Point and You Tube, giving quiz and homework through Google form. Thus, the teacher's beliefs has implicated in the English teaching and learning at Sanggar Kegiatan Belajar and CALL is useful for English teaching and learning process at Sanggar Kegiatan Belajar.
\end{abstract}

Keywords: teacher's beliefs, CALL, English teaching and learning process, implication of teacher's beliefs

\section{Introduction}

These days, the development of science and technology achieved has contributed to the advance in language teaching and learning. Nowadays, language teachers utilize computer and internet with their software and facilities for the purpose of teaching and learning activities in the classrooms. Computer assisted language learning (CALL) means "the search for and study of applications on the computer in language teaching and learning” (Levy, 1997). 
Other definition comes from Richards and Schmidt (2002). They stated that CALL is an activity which is parallel learning through other media. CALL uses the facilities of the computer (e.g. using the computer to present a reading text). Besides, Hashemi and Aziznezhad (2011) propose that "CALL offers modern English language teachers many facilities and novel techniques for teaching and learning". Therefore, it can be concluded that CALL is the tools or applications in the computer that can be parallel and used for language teaching and learning process.

There are some advantages of CALL have been investigated. Firstly, it helps to generate autonomous learners who will experience freedom of choice, and gives a new role to teaching materials (Azmina, B., Fauziati, E., \& Drajati, N. A., 2018). Secondly, by integrating computers in language testing, teachers can save time since the computers do all the evaluation and calculation for teachers (Chapelle, 2001). Thirdly, by adopting CALL software programs (e.g. educational CDROM packages) into the curriculum, the task of the teacher becomes easier (Levy, 1997) since these kinds of software programs give teachers the opportunity of assessing their students' levels more easily than assessing by using the students' records.

However, the implication on integrating CALL is based on the teacher's belief toward CALL. This is because "what teachers do reflect what they believe" (Fauziati, 2015). Borg (2001) defined that a belief is a proposition which may be consciously or unconsciously held, is evaluative in that it is accepted as true by the individual, and is therefore imbued with emotive commitment; further, it serves as a guide to thought and behaviour. Beliefs help teachers to make sense of what they experience in the classroom, they create meaning for teachers. Watson (2006, in Leftwich, Anne \& Glazewski, Krista \& Newby, Timothy \& Ertmer, P.,2010) found out that teachers' value beliefs with regards to the technology are based on whether or not they think technology can help them achieve the instructional goals they perceive to be most important. Teachers' reasons for using technology in the classroom usually relate to their beliefs that technology can address important teaching and learning needs (Judson, 2006; Zhao\& Frank, 2003).

Several previous studies have been conducted to investigate the teacher's belief and the implication on integrating CALL in the formal schools. Lim \& Chai (2008) found that five out of the six teachers we interviewed were reportedly inclined towards constructivist notion of teaching. The participants accounted for the inconsistency between their espoused beliefs and the teacher-centric teaching practice as due to contextual constraints. Azmina, B., Fauziati, E., \& Drajati, N. A. (2018) found that the participant's belief that the roles of the computer taking in language learning are as a tool, a surrogate teacher, a useful provider of mechanical language practice, a manager of tasks, and an aid to communication. 
However, the use of CALL (Computer Assisted Language Learning) for language teaching and learning is not only at formal school such as elementary school, high school and university, but it is also used at informal school such as Sanggar Kegiatan Belajar (SKB). SKB is an informal school for getting equality degree. The researcher has observed the English teacher who has used the computer for the teaching and learning process at SKB. This research wants to intestigate teacher's belief and its implication on integrating CALL in English class at SKB (Sanggar Kegiatan Belajar).

\section{Literature review}

\section{Teachers' belief}

There are some definiton of teachers' belief from experts. The first expert comes from Kagan (1992). Kagan (1992) stated that teachers' beliefs as "tacit, often unconsciouslyheld assumptions about students, classrooms, and the academic material to be taught". On the other hand, Borg (2001) defined belief as proposition which may be consciously or unconsciously held. Teachers' beliefs can be said as assumptions about students, classrooms, and academic materials imbued with commitment to reflect their beliefs on the method or strategy they use. William and Burden (1997 in Fauziati, 2015) affirmed that teacher beliefs play an important role in the language learning process. For this reason, teachers must understand their own beliefs.

Richards and Lockhart (1994) provide guide lines for English teachers and researchers for the investigation of teachers' belief which includes beliefs, namely: belief about English, belief about learning, belief about teaching, belief about the program and curriculum, and belief about teaching as profession.

a. Belief about English:

English represents different things to different people. For some it represents the language of English literature; for others it is the language of the English-speaking world. For Indonesian students, in general, English represents a compulsory school subject to learn. It is therefore crucial to examine the underlying beliefs teachers have about English and how they influence their attitude in teaching it.

b. Belief about Learning

It is impossible to observe teaching in isolation from learning. Teachers' belief about learning reflects everything that they do in the classroom.

c. Belief about teaching

Teaching is a very personal activity, and it is not surprising that individual teachers bring to teaching very different beliefs and assumptions about what constitutes effective teaching. This can be seen by comparing the 
following descriptions of how two English teachers conduct their classes in a secondary school in an EFL country.

d. Beliefs about Program and the Curriculum

Any language teaching program reflects both the culture of the institution (i.e., particular ways of thinking and of doing things that are valued in the institution), as well as collective decisions and beliefs of individual teachers.

e. Belief about Language Teaching as a Profession

Teachers' beliefs about professionalism can be explored through questions such as the following:

1. How would you characterize English teaching (or the language you teach) as a profession?

2. What changes do you think are necessary in the language teaching profession?

3. What kind of training do you think language teachers need?

4. What kinds of professional development activities best support teaching?

5. What kind of support for professional development is available at a school you are familiar with?

6. What is the most rewarding aspect of teaching for you?

7. Do you think language teachers should be evaluated throughout their careers? If so, what form should this evaluation take?

\section{Computer assisted language learning}

In this century, computer assisted in the language learning in many developing countries especially in Asia, including Indonesia. Computer Assisted Language Learning (CALL) is the search for and study of applications of the computer in language teaching and learning (Levy, 1997). Levy's definition has a relationship with the real condition of language teaching and learning process.

Richards and Schmidt (2002) stated that CALL is an activity which is parallel learning through other media. CALL uses the facilities of the computer (e.g. using the computer to present a reading text). Moreover, they add CALL as activities that are extensions or adaptations of print-based or classroom-based activities e.g. computer programs that teach writing skills by helping the students developing a topic and thesis statement and by checking a composition for vocabulary, grammar, and topic development. CALL is often perceived, somewhat narrowly, as an approach to language teaching and learning in which the computer is used as an aid to the presentation, reinforcement, and assessment of material to be learned, usually including a substantial interactive 
element. CALL is a method of teaching and learning languages by means of computer software specially designed to use in the classroom.

The application or program integrated in the computer helps the teachers and the learners to learn. The application could be material in a form of text, audio, and video. The teaching and learning process is started from the planning process, making a lesson plan and preparing material. Then, the program demonstrates the material to the students that followed by real practice. Next, the computer also can manage the assessment and evaluation to the study.

After many years later, there are various attempts that have been made since CALL became available to a wider audience to establish a CALL typology and to document the changing phases of CALL (Davies G., Walker R., Rendall H. \& Hewer S., 2012). Typology is the study of types, in this part there are some types of CALL programs based on a finding by some researchers (Davies G., Walker R., Rendall H. \& Hewer S., 2012):

\section{1) Davies and Higgins (1985)}

Davies and Higgins (1985) identify the following types of CALL programs

a. Gap-filling exercises: GapKit (Camsoft), Gapmaster (Wida)

b. Multiple-choice exercises: Choicemaster (Wida)

c. Free-format exercises: CLEF (Camsoft), Testmaster (Wida)

d. Tutorial programs: CLEF (Camsoft)

e. Re-ordering: Word Sequencing (ESM and Camsoft), Textsalad (Camsoft)

f. Simulations: Granville (Cambridge University Press), Montevidisco interactive videodisc (v. Schneider and Bennion 1984)

g. Text mazes (also known as action mazes): Mazes (NCCALL, adapted from Berer and Rinvolucri 1981)

h. Adventures: French on the Run (Gabriel Jacobs, Silversoft)

i. Games: Vocab (Wida)

j. Cloze: Clozewrite (Camsoft), Clozemaster (Wida)

k. Text manipulation: Fun with Texts (Camsoft), Storyboard (Wida)

1. Exploratory programs: S-End ing (v. Higgins and Johns 1984: 71ff.)

$\mathrm{m}$. Writing - word-processing

Nowadays, the types from Davies are used in the CALL programs as the types of specific activities in teaching and learning process.

\section{2) Jones and Fortescue (1987)}

These are the list of types of CALL programs identified by Jones and Fortescue (1987):

a. Grammar: Matchmaster, Choicemaster, Testmaster (Wida)

b. Vocabulary: Vocab (Wida) 
c. Reading skills: Storyboard (Wida)

d. Authoring programs: the Wida series (now known as The Authoring Suite)

e. Writing - word-processing

f. Oral skills - using simulations and adventures as a stimulus: London Adventure (Cambridge University Press) and Yellow River Kingdom

g. Listening skills: Getting the Message interactive videodisc (Glyn Jones, Euro centre)

h. Information source: Wordstore (Wida)

i. Discovery and exploration: Loan (Higgins and Johns 1984: 73f.)

j. Jones and Fortescue design the types of CALL program from the language learning skills. The skills are listening, speaking, writing, reading, and the sub skills from them.

\section{3) Hardisty and Windeatt (1989)}

Hardisty and Windeatt (1989) draw up this simpler classification of four basic types of CALL programs:

a. School programs: exercises involving gap-filling, multiple-choice, sequencing, matching, total text reconstruction.

b. Office programs: word-processing, database, DTP, communications, spreadsheets.

c. Library programs: concordances - and they would probably have included the Web if it had been around at the time.

d. Home programs: adventures and simulations.

The last, types from Hardisty and Windeatt were designed to fulfil the specific needs for the learners.

There are some advantages of CALL. First, the use of computers provides teachers with the opportunity of making better use of their time and expertise by handling a number of mechanical tasks such as correcting and marking exercises. This will allow more time for preparing lessons and activities like discussions, presentations and project work. By integrating computers in language testing, teachers can save time since the computers do all the evaluation and calculation for teachers (Chapelle, 2001).

Second, by adopting CALL software programs (e.g. educational CDROM packages) into the curriculum, the task of the teacher becomes easier (Levy, 1997) since these kinds of software programs give teachers the opportunity of assessing their students' levels more easily than assessing by using records of the students. Moreover, package software programs offer teachers the opportunity to see the records that show how much time was spent on each question or part by the student. Thus, teachers have the opportunity to observe the students and analyse what goes on in their classrooms and reassess the main principles of the learning and teaching process while students are working on their own. In that case the 
design of computer laboratories is also important. Ideally, these should be designed in order to make both pair and group work or individual study possible and to make observation of students by the teacher easier (Kenning \& Kenning, 1983).

\section{Previous studies}

Some studies have been conducted on teacher's belief on CALL and its implementation. The first study has been conducted by Lim \& Chai (2008). The study found that five out of the six teachers interviewed were reportedly inclined towards constructivist notion of teaching. The participants accounted for the inconsistency between their espoused beliefs and the teacher-centric teaching practice as due to contextual constraints. This case study therefore highlights that although it is necessary for teachers to hold pedagogical beliefs that are compatible with the constructivist notion of teaching and learning, this is an insufficient condition to shift traditional teaching practice. Changes in assessment systems and substantial professional development are further conditions that have to be addressed.

Another research on teachers' beliefs which in the context of the integration of technology that has been identified as influencing teachers' changes decision (Chamorro and Rey, 2013). This study was to examine what teachers believe about the effectiveness of using technology in an English program at university level and how these beliefs affect the use of these types of tools in their classes. The research conducted was a qualitative study and the analysis of data revealed that the use of technology-based activities in the English classroom is twofold: reinforcing already studied topics in class and promoting motivation.

The third research is conducted by Morales (2014). The goal of this study is to demonstrate the positive impact that technology has in second language teaching/learning, and how the lack of training for second language teachers deprives the students of the potential benefits that technology can bring to L2 classrooms. The data for this research were collected from eight fulltime high school foreign language teachers. The results of the study show that teachers tend to use technology in second language teaching/learning in an inconsistent way due to the lack of appropriate training and their unfamiliarity with the technology. Additionally, the lack of frequent CALL usage as an important tool by teachers and students diminishes the potential for students of become more independent learners due to the technology ease of access beyond the classroom and the absence of time-limitations to learn and practice L2. CALL has the possibility to enhance the second language learning experience when teachers are well-trained to use it, and it is done consistently throughout the school year. 
The fourth study is conducted Dwiyanti (2013). The aim of this research is to describe the implementation of CALL in teaching and learning of business English for students of SMK N I Depok, Sleman, Yogyakarta. It focuses on the description of the availability and the accessibility of hardware and courseware, the teachers' control, the learner use of courseware, and one additional point; it is the teachers' understanding of the implementation of CALL. In conclusion, the implementation of CALL/HL in SMK N 1 Depok has fulfilled most of the implementation components.

The other study has been conducted by Azmina, et.al (2018). This study investigates teacher's beliefs on the implementation of CALL approach for higher education. This is a qualitative research using case study design. Data obtained in this study are from interview and documentation from one English lecturer. The result shows that, to him CALL means an activity where students learning a language using computers in the presence of a teacher. His beliefs of the roles the computer taking in language learning are as a tool, a surrogate teacher, a useful provider of mechanical language practice, a manager of tasks, and an aid to communication. The significance of this study is as a reflection for English language educators teaching CALL as a subject in higher education, whether it follows the theories of CALL or not, so that, they can get further CALL training or any programs for better implementation.

The last study has been conducted by Onsoy (2004). This study investigated the attitudes of students and teachers towards computers and the use of CALL, the similarities and differences between their attitudes and factors that affect students and teachers' use of CALL program at the Preparatory School of Celal Bayar University. The data was collected through questionnaires distributed to 191 students and 22 teachers in a 30 \% English-medium university. In order to get in-depth results, interviews were conducted with 4 teachers based on the results of the questionnaires. The results of the findings gathered from students' questionnaires revealed statistically significant differences in terms of level of the students. The findings indicated no differences between the attitudes of students and teachers towards computers and the use of computers in language instruction in general.

\section{Method}

The type of the research is qualitative research. According to Ary (2010), qualitative research focuses on understanding social phenomena from the perspective of the human participants in natural settings. Thus, the researchers just focus on investigated the phenomenon in their society relates to human behaviour, holistic picture of the social and cultural setting which is creating by people in their environments. It does not begin with formal hypotheses, but it 
may result in hypotheses as the study unfolds. The hypotheses are derived commonly from the specific problem of the previous research, theory of education, sociology, and psychology. It is always called as inductive way which the researcher makes observations, think problem, turn to literature, additional information then hypotheses.

Qualitative research is an approach for exploring and understanding the meaning individuals or groups describe to a social or human problem. It is done by describing and reporting views of people who involve within the research. There are eight qualitative designs mentioned by Ary (2010) namely basic interpretive studies, case study, document or content analysis, ethnography, grounded theory, historical studies, narrative inquiry and phenomenological study. The data of qualitative research are collected and recorded in description and does use neither symbol nor numbers. The source in qualitative research is usually called informant.

The researcher uses case study as the design of the study. Stake (1995) describes case studies as "the study of a particularity and the complexity of a single case, coming to understand its activity within important circumstances". In line with Yin (2003), he defines case study method as "an empirical inquiry that investigates a contemporary phenomenon within its real life context". Simons (2009) states that "Case study is an in-depth exploration from multiple perspectives of the complexity and uniqueness of a particular project, policy, institution, program or system in a 'real life"'

Therefore, it can be concluded that case study is an in-depth and empirical inquiry that investigates a contemporary phenomenon, a particularity and multiple perspectives of the complexity and uniqueness of a single case, project, policy, institution, program or system, coming to understand its activity in a real life.

\section{Participants}

The participant is the teacher at Sanggar Kegiatan Belajar Karanganyar. The participant is purposively selected in order to get sufficient data of this research. The teacher has used the computer in the language teaching and learning process.

\section{Procedure}

The researcher conducted the observation in the place where the teacher used CALL integration in the English teaching process. The researcher then gave the questionnaire and did the interview to the teacher related to teachers' belief and the implication on integrating CALL. After getting the data, the researcher analyzed the data by displaying and describing the result of the research data obtained. 


\section{Data collection}

In this study, researcher will use observation, questionnaire, in-depth interview and documentation.

\section{a. Observation}

Observation is a method of collecting data using observation to research object. Nasution in Sugiyono (2011, p. 226) states that observation is the basis of all sciences. The writer observed the participants in the teaching learning process in the class.

b. Questionnaire

The writer adapted the questionnaire from Onsoy (2004) which investigated the attitudes of students and teachers towards computers and the use of CALL.

\section{c. In-depth interview}

According to Berg (2007), in-depth interview is a process to obtain information for the purpose of research by face to face questioning between the interviewer and informant or interviewee, with or without the use of an interview guide. In this part the writer will check the similarity of the results between the questionnaire and in-depth interview. At this stage the writer can search to produce detailed information using records and notes.

\section{Data analysis}

In this study, the researcher used technique of data analysis based on Miles and Huberman (1994) which is involving three steps: data reduction, data display, and conclusion drawing/verification.

\section{a. Data reduction}

The first step in analysing qualitative data involves data reduction. Data reduction means summarizing, choose the basic things, focusing on important things, look for themes and patterns (Sugiyono, 2011). Firstly, the researcher collected data about the belief and its implementation on integration CALL through questionnaire, interview and observation. The researcher then transcribed the data. Next, after collecting and reducing the data, the researcher displayed those data in the form of descriptive.

\section{b. Data display}

The second step is data display. A display is an organized, compressed assembly of information that permits conclusion drawing and the action (Miles and Huberman, 1994). In the process of the reducing and displaying the data, it was based on the formulation of the research problem. The formulation of the research problems are: 1) What is the teacher belief? And 2) What is the 
implication on integrating CALL in English class at SKB (Sanggar Kegiatan Belajar). This step is done by presenting a set of information that is structured and possibility of drawing conclusions, because the data obtained during the process of qualitative research usually in the form of narrative, thus requiring simplification without reducing its contents. After displaying the data, a conclusion is drawn.

\section{c. Conclusion drawing/verification}

The third step of qualitative data analysis is conclusion drawing and verification. From the start of data collection, the qualitative analysis is beginning to decide what things mean is noting regularities, patterns, explanations, possible configurations, causal flows, and propositions (Miles and Huberman, 1994). Conclusions are also verified as the analyst proceeds. The conclusion drawing is started after the data were collected 38 by making temporary conclusion. In the other words, it can be said that the conclusion is analysed continuously and verified the validity to get the perfect conclusion about the teacher's belief and its implication on integrating CALL.

\section{Findings and discussion}

The researcher used questionnaire and interview for conducting the research. The questionnaire is adapted from Onsoy (2004) and the interview is made by the researcher for reaching the deeper data.

The questionnaire consists of four parts. They are background information, general opinion, and teacher's belief. The background information section consists of the participant's information such as age, sex, and years of teaching experience. The general opinion section consists of two parts. They are how the participant often use computer and what participant use computer for. The third section of the questionnaire is teacher's belief. It consists of fourteen statement which the participant should answer.

The participant is a female in the age 20-25. She has teaching experience for 1-4 years. She works at Sanggar Kegiatan Belajar at a Regency in Central Java. It is an informal equality school. She uses computer for five or more times a week. She often uses computer for making materials design, typing and maintaining lesson plans, office work, student records, and administrative reports, surfing internet, assigning and checking assignments via email, chat rooms and web page design. She sometimes uses computer for electronic mail, online shopping, and entertainment. She rarely uses computer for games.

Here are the results of the questionnaire which related to the teacher's belief on CALL. 
Table 1. Result of the questionnaire

\begin{tabular}{|c|c|c|c|c|}
\hline No. & Statement & $\begin{array}{ll}\text { Strongly } & \text { Disagree } \\
\text { Disagree } & \\
\end{array}$ & Agree & $\begin{array}{l}\text { Strongly } \\
\text { Agree }\end{array}$ \\
\hline Q1 & I like using computers. & & & $\sqrt{ }$ \\
\hline Q2 & $\begin{array}{l}\text { I generally have positive } \\
\text { beliefs } \\
\text { computers. }\end{array}$ & & & $\sqrt{ }$ \\
\hline Q3 & $\begin{array}{l}\text { Using computers makes } \\
\text { me more efficient in my } \\
\text { life. }\end{array}$ & & & $\sqrt{ }$ \\
\hline Q4 & $\begin{array}{l}\text { Using computers make } \\
\text { me more efficient at work. }\end{array}$ & & & $\sqrt{ }$ \\
\hline Q5 & $\begin{array}{lr}\text { Using r r r } & \text { computers } \\
\text { generally } & \text { makes } \\
\text { completing tasks easier. }\end{array}$ & & & $\sqrt{ }$ \\
\hline Q6 & $\begin{array}{l}\text { I like searching the } \\
\text { internet for general } \\
\text { interest. }\end{array}$ & & $\sqrt{ }$ & \\
\hline Q7 & $\begin{array}{l}\text { I perceive computers as } \\
\text { pedagogical tools. }\end{array}$ & & $\sqrt{ }$ & \\
\hline Q8 & $\begin{array}{l}\text { I generally have positive } \\
\text { beliefs towards using } \\
\text { computers in language } \\
\text { instruction. }\end{array}$ & & $\sqrt{ }$ & \\
\hline Q9 & $\begin{array}{l}\text { I like using computers for } \\
\text { teaching purposes. }\end{array}$ & & $\sqrt{ }$ & \\
\hline Q10 & $\begin{array}{l}\text { I like searching the } \\
\text { internet for teaching } \\
\text { resources. }\end{array}$ & & & $\sqrt{ }$ \\
\hline Q11 & $\begin{array}{l}\text { Computers can be a good } \\
\text { supplement to support } \\
\text { teaching. }\end{array}$ & & & $\sqrt{ }$ \\
\hline Q12 & $\begin{array}{l}\text { Computers can be a good } \\
\text { supplement to support } \\
\text { learning. }\end{array}$ & & $\sqrt{ }$ & \\
\hline Q13 & $\begin{array}{l}\text { I believe that training is } \\
\text { required to teach with } \\
\text { computers. }\end{array}$ & & $\sqrt{ }$ & \\
\hline Q14 & $\begin{array}{l}\text { I think that I need } \\
\text { training to teach with }\end{array}$ & & $\checkmark$ & \\
\hline
\end{tabular}


computers.

There are fourteen statements in the questionnaire. The first statement is "I like using computers." The result of first statement shows that the participant strongly agrees that she likes using computers.

The second statement is "I have positive beliefs towards computers." The result of the second statement shows that the participant strongly agrees that she has positive beliefs towards computers.

The third statement is "By using computers makes her more efficient in life." The result of the third statement shows that the participant strongly agrees that by using computers makes her more efficient in life.

The third statement is "By using computers make me more efficient at work." The result of the third statement shows that the participant strongly agrees that by using computers make me more efficient at work.

The fourth statement is "By using computers generally makes completing tasks easier." The result of the fourth statement shows that the participant strongly agrees that by using computers generally makes completing tasks easier.

The fifth statement is "By using computers generally makes completing tasks easier." The result of the fifth statement shows that the participant strongly agrees that by using computers generally makes completing tasks easier.

The sixth statement is "I like searching the internet for general interest." The result of the sixth statement shows that the participant agrees that she likes searching the internet for general interest.

The seventh statement is "I perceive computers as pedagogical tools." The result of the seventh statement shows that the participant agrees that she she perceives computers as pedagogical tools.

The eighth statement is "I generally have positive beliefs towards using computers in language instruction." The result of the eighth statement shows that the participant agrees that she generally has positive beliefs towards using computers in language instruction.

The ninth statement is "I like using computers for teaching purposes." The result of the ninth statement shows that the participant agrees that she likes using computers for teaching purposes.

The tenth statement is "I like searching the internet for teaching resources." The result of the tenth statement shows that the participant strongly agrees that she likes searching the internet for teaching resources.

The eleventh statement is "Computers can be a good supplement to support teaching." The result of the eleventh statement shows that the participant strongly agrees that computers can be a good supplement to support teaching. 
The twelfth statement is "Computers can be a good supplement to support learning." The result of the twelfth statement shows that the participant agree that computers can be a good supplement to support learning.

The thirteenth statement is "I believe that training is required to teach with computers." The result of the thirteenth statement shows that the participant agrees that she believes that training is required to teach with computers.

The fourteenth statement is "I think that I need training to teach with computers." The result of the fourteenth statement shows that the participant agrees that she thinks that she needs training to teach with computers.

From fourteen statements, the participant stated strongly agrees for seven statements and agree for the other seven statements. It can be concluded that she has high belief towards CALL integration in English teaching learning process. Furthermore, the researcher also conducted observation and interview towards the implication on CALL integration in her class. According to the observation, firstly the participant used power point and YouTube for explaining materials. The participant also stated when she has been interviewed that "I use power point for explaining materials or YouTube because the students prefer to animation". It can be assumed that when the participant uses PowerPoint or YouTube, the students feels motivated or happier because there is animation.

Secondly, the participant also gave quiz for the students by giving them google form link. After explaining the material to the students, the participant gives the quiz through google form which the participant has made. The participant stated that "The students are more enthusiastic because they cannot cheating and the score automatically appears after they have done" and "If the score is bad, we can do a remedial test with the same questions."

Besides quiz, the participant sometimes also gave the assignment or homework through google form. She gives the link of the google form to the students then asks the students to do the assignment. If the students face difficulty in answering question, they can have consultation time to the teacher. It makes the students easier because the students at SKB also have jobs so they can consult the difficulty to the teacher in anytime.

When the participant has been asked about the advantages and challenge of the implication on CALL, she answered "The advantages are: Firstly, it makes me save energy, but I have to be more diligent to make more questions in google drive. Secondly, it is more efficient because I can use it for many classes. So, I make some questions in a chapter once, and I can use it many times for different classes". She added "The challenge is if I give them homework through Google form, I cannot monitor whether they do by themselves or are helped by their friends."

Regarding to the teacher's belief questionnaire, observation and interview, the result of the study finds out that the teacher has high belief towards CALL integration in teaching and learning English. The study also shows that the 
participant also implies CALL integration in her classes, such as explaining the materials through power point or YouTube, giving quiz through Google form, and giving homework through google form. The result of this study is in line with Onsoy (2004) that indicated the students and teachers demonstrated positive attitudes towards the use of computers in daily tasks and in language instruction.

Furthermore, the participant also gets some advantages from integrating CALL in her classes. They are: 1) It saves energy and 2) it makes efficient. This result is in line with Chapelle (2001) that by integrating computers in language testing, teachers can save time since the computers do all the evaluation and calculation for teachers by integrating computers in language testing, teachers can save time since the computers do all the evaluation and calculation for teachers. It is also in line with (Levy, 1997) since these kinds of software programs give teachers the opportunity of assessing their students' levels more easily than assessing by using the students' records.

\section{Conclusion}

The result of this study shows that the teacher has positive belief towards CALL integration in English teaching and learning process. Besides, the participant also implied the CALL integration by explaining materials through PowerPoint and YouTube, giving quiz and homework through Google form. The study suggests to further investigation of students' belief towards CALL integration.

\section{References}

Ary, Donald, Jacobs, L.C, Sorensen, C. and Razavieh, A. (2010). Introduction to research in education (8th ed). USA. Wadsworth, Cengage Learning.

Azmina, B., Fauziati, E., \& Drajati, N. A. (2018). Teacher's beliefs on the implementation of computer assisted language learning (CALL) Approach for higher education students. The International English Language Teachers and Lecturers Conference (iNELTAL). Retrieved from http://ineltal.um.ac.id/wp-content/uploads/2019/03/Badiatul-Azminapage-195-200.pdf

Berg, B. L. (2007). Qualitative research methods for the social sciences. London: Pearson.

Borg, Michael. (2001). Teachers beliefs. ELT Journal Volume 55, 2 April 2001, 55 (2): 186-188. Oxford University Press.

Chamorro, Martha Gracia and Rey, Lourdes. (2009). Teachers' beliefs and integration of technology in the EFL class. HOW 2O, October 2013, ISSN 012O-5927, 51-72. Bogota, Colombia. Retrieved from https://dialnet.unirioja.es/descarga/articulo/5249715.pdf

Chapelle, C. A. (2001). Computer application in second language acquisition. Computer Applications in Second Language Acquisition: Foundations 
for Teaching, Testing and Research. Cambridge: Cambridge University Press.Retrieved from http://assets.cambridge.org/97805216/2646o/frontmatter/9780521626 460_frontmatter.pdf

Davies G. \& Higgins J. (1985) Using computers in language learning: A teacher's guide. London: CILT.

Davies G., Walker R., Rendall H. \& Hewer S. (2012) Introduction to Computer Assisted Language Learning (CALL). Module 1.4 in Davies G. (ed.) Information and Communications Technology for Language Teachers (ICT4LT), Slough, Thames Valley University [Online]. Retrieved from http://www.ict4lt.org/en/en_mod1-4.html

Dwiyanti, Anik. (2013). The implementation of CALL (Computer-assisted language learning) in the teaching and learning of business English for students of SMK N I Depok, Sleman, Yogyakarta. Thesis.Universitas Negeri Yogyakarta.

Ertmer, Peggy. And Leftwich, Anne T. O. (2010). Teacher technology change: How knowledge, confidence, beliefs and culture intersect. Journal of Research on Technology in Education, 42(3), pp.255-284.

Fauziati, E. (2015). Teacher Beliefs, Teaching English as a foreign language: Principle and practice. Surakarta: Era Pustaka Utama.

Hardisty D. \& Windeatt S. (1989). CALL. Oxford: Oxford University Press.

Hashemi, M., \& Aziznezhad, M. (2011). Computer assisted language learning freedom or submission to machines? Procedia - Social and Behavioral Sciences, 28, pp. 832-835. Retrieved from https://doi.org/10.1016/j.sbspro.2011.11.152

Jones C. \& Fortescue S. (1987). Using computers in the language classroom. Harlow: Longman.

Judson, E. (2006). How teachers integrate technology and their beliefs about learning: Is there a connection? Journal of Technology and Teacher Education, 14.

Kagan, D. M. (1992). Implications of research on teacher belief. Educational Psychologist, 27, 65-90. Retrieved from https://doi.org/10.1207/s15326985ep2701_6

Kenning, M. J., \& Kenning, M. M. (1983). An introduction to computer-assisted language learning. Oxford: Oxford University Press.

Levy, M. (1997). Computer-assisted language learning: Context and conceptualization. Oxford: Oxford University Press.

Lim, C. P., \& Chai, C. S. (2008). Teachers' pedagogical beliefs and their planning and conduct of computer-mediated classroom lessons. British Journal of Educational Technology. 39 (5). Retrieved from https://doi.org/10.1111/j.1467-8535.2007.00774.x

Miles, M. B., \& Huberman, A. M. (1994). Qualitative data analysis: An expanded sourcebook. Thousand Oaks, CA: SAGE.

Morales, Nelson E. (2014). Use of computer assisted language learning. The College at Brockport: Thesis.

Onsoy, Seden. (2004). Students' and teachers' attitudes towards the use of computer-assisted language learning at the preparatory school of Celal Bayar University. Thesis. 
Ottenbreit-Leftwich, Anne \& Glazewski, Krista \& Newby, Timothy \& Ertmer, Peggy. (2010). Teacher value beliefs associated with using technology: Addressing professional and student needs. Computers \& Education 144: 1321-1335. Retrieved

from https://doi.org/10.1016/j.compedu.2010.06.002

Richards, Jack C. and Lockhart, Charles (1994). Reflective teaching in second language classrooms. Cambridge: Cambridge University Press

Richards, Jack. C and Schmidt, Richard. 2002. Longman dictionary of language teaching and applied linguistics. Britain: Longman.

Simons, H.(2009). Case study research in practice. London: SAGE

Stake, R. (1995). The art of case study research (pp. 49-68). Thousand Oaks, CA: SAGE.

Sugiyono (2011). Statistik untuk penelitian. Bandung: Alfabeta

Yin, Robert K. (2003). Case study research: Design and methods. Applied Social Research Method Series Volume 5. Sage Publications.

Zhao, Y., and Frank, K. A. (2003). Factors affecting technology uses in schools: An ecological perspective. American Educational Research Journal, 40. 